\title{
I Krigens Vold.
}

VII.

\author{
Thorvald Dau.
}

Ved H. Lausten Thomsen.

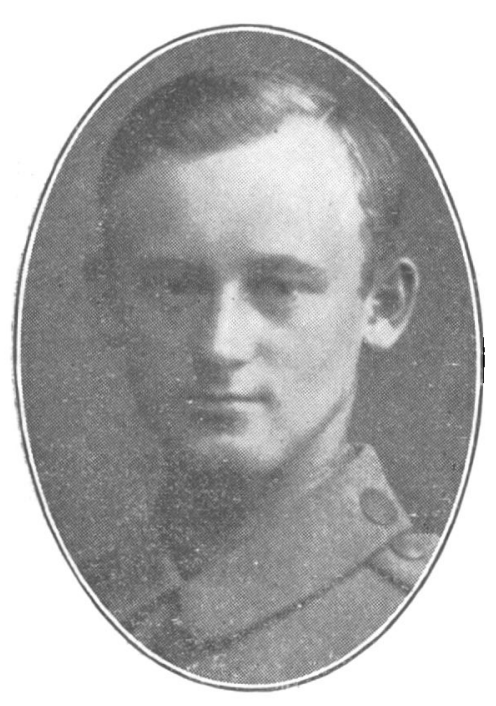

Thorvald Dau er født den 16. oktober 1891 paa Broballe mejeri. Efter sin konfirmation lærte han landvæsen hos forskellige landmænd i Nordslesvig, ligeledes paa Tystofte forsøgsstation og paa Bavngaard. Han tilbragte 5 maaneder paa Vester Vedsted efterskole og ligeledes paa Ryslinge højskole. I. efteraaret 1913 blev han indkaldt som soldat og fik derved sin uddannelse som landmand afbrudt. Nationalitetskampen interesserede ham stærkt.

Thorvald Dau var et af de unge mennesker, man turde vente sig noget af i Senderjylland. Sund, opvakt, interesseret, og nu ligger han paa den sønderjydske kirkegaard i Braisne. 
Hans moder har smukt og møjsommeligt afskrevet alle hans mange breve, hvoraf her bringes nogle udtog. Hans danskhed skinner igennem paa hver side; men efter hans faders ønske aftrykkes uden for sammenhængen med de andre breve et par brudstykker, hvor han taler direkte om den:

\section{Kalisch, d. 20. 3. 15.}

...... Alligevel lever jeg nu den bedste tid, siden jeg forlod skyttegraven. Jeg er bleven forstanderens gode ven. I maa nu ikke tro, at jeg gaar og fedter for ham. Vi har saa at sige haft hinanden i harene et par gange. Han saa nemlig, at jeg skrev dansk, og saa begyndte han at spørge, om jeg kunde dansk, om jeg havde været i København o. s. v. En anden dag, da jeg skrev igen, sagde han, at jeg fortalte vel ikke danskerne militære hemmeligheder. Han troede det eller mente det selvfølgelig ikke saa slemt. Jeg sagde nu, at han behøvede ikke at være bange, jeg havde flere Russere paa min samvittighed end saa mangen tysker. I skulde have set ham fare op. Hvis min far og mor ogsaa havde været dansk, saa var jeg dog en tysker nu. Det var ikke saa nemt, sagde jeg. Saa begyndte han et helt foredrag for mig om, at Danmark gjorde bedst $i$ at gaa ind under Tyskland ligesom Bayern o. s. v. Jeg var nu ikke meget for at diskutere om dette sporgsmaal under disse forhold. Som soldat maa man jo ogsaa tage hensyn, naar man har en officer foran sig. Jeg tav stille, og saa begyndte han at rose danskerne. Danskerne var pæne folk. København, den dejlige hovedstad ved havet, besøgte han hver sommer. Han var bleven helt imponeret af den danske garde. En Gardeoberst, Wolf, 
havde han besøgt en gang. Det danske artilleri var ogsaa brilliant. Derefter fortalte han om de dejligste damehatte, hans kone havde fundet paa stroget. Om det var handskerne, fik de ogsaa deres. Damehatte og handsker er jo artikler, jeg har haft meget lidt brug for, men at de ikke skulde være lige saa gode og pæne som den danske garde, tvivler jeg ikke paa. Nu kalder han mig ikke andet end "Kleiner Däne". Det maa han ogsaa godt. Sommetider om aftenen, naar jeg hjælper ham overfrakken paa, bliver han staaende og fortæller mig nogle københavnerhistorier. En aften, han var særlig oplagt, gav han mig haanden, da han sagde godnat. Fortæl deres forældre, naar de skriver, at her har vi en læge, der holder meget af danskerne. Det har jeg nu ogsaa gjort.

Selv om det ikke er saa markeligt, at en fremmed mand kan imponeres af Danmark, saa synes mig dog, at her har jeg mødt noget, der imponerer mig. Tænk, han - den tyske officer - fortæller en menig, der gør sig lidt stædig, at hans stamme er pæne folk. Denne mand er jeg altsaa kommen til at holde lidt af. Det er ikke hver dag, man møder dem her. Han skal være en meget kendt læge gennem sine artikler $i$ forskellige fagskrifter. Jeg er altsaa ikke saa ked af at være her som i begyndelsen.«

Den 12. februar 1918 skrev Thorvald Dau til sine forældre:

"I middags, da jeg havde et ærinde i byen, traf jeg vor kompagnifører. Han tiltalte mig med følgende ord: "Ved de, hvorfor de ikke har været hjemme saa længe?« Paa mit benægtende svar svarede han, at der nu ingen flere maatte sendes saa højt mod nord paa orlov. Han spurgte saa om, hvor længe det var 
siden, at jeg havde været hjemme, og om der for havde været noget $i$ vejen for $\min$ hjemrejse. Jeg svarede, som rigtigt er, at min sidste orlov var julen 1915, og kun omstændigheder i Rumænien og de mange transporter $\mathbf{i}$ den korte garnisonstid i sommer havde bevirket den lange fraværelse. Ja, det gjorde ham meget ondt. Han vilde se at gøre for mig, hvad der lod sig gøre, og hvis ikke, saa kunde jeg maaske rejse til en anden by. Det hele kom lidt bag paa mig. Jeg svarede, at jeg havde familie i Rendsborg. Kunde jeg heller ikke komme derhen, kunde jeg nok være en ferie i Osterode. Jeg tænkte da ikke paa, at det vil være en umulighed for dem i Rendsborg at have mig. Derimod vilde jeg nok kunne opleve en god tid i Osterode og saa maaske faa lov til at rejse til Flensborg. Det vil jeg dog tale med kompagniføreren om ved første Lejlighed. Saadan staar mit orlovsforhold nu. Jeg ved endnu ikke, om det er kompagniføreren, der af sin frie vilje har forsøgt at faa mig til at rejse allerede $i$ den nærmeste tid, eller om det kun er forberedelse, til jeg er paa tour. I hvert fald staar jeg nu over for det mærkelige, at jeg fra min kompagnifører er genstand for den videstgaaende velvilje, som jeg jo maa have vundet direkte foran fjenden, medens en tosset bestemmelse hindrer mig $i$ et længe fortjent berettiget krav.

Underlige tilstande, nu har jeg været hjemmefra i 25 maaneder, været saaret 2 gange, er bleven dekoreret 2 gange og nu til sidst forfremmet til underofflcer, skønt jeg kun har været langt kortere tid ved kompagniet end flere andre, som ogsaa havde haft udsigt til forfremmelse, men maatte staa tilbage for mig. Det er ikke for at prale, jeg skriver dette; men at der efter dette her skulde være en fare for, at jeg 
skulde svigte min pligt paa orloven, forekommer mig latterligt. Og skudsmaalet her fra fronten havde vel nok været mere afgørende end natpotternes derhjemme. Nu skal vi se, hvad det kan blive til. Fedte mig til min ret falder mig ikke ind. At nogle gaar over grænsen, har man ikke lov til at beskylde danskerne alene for. Ved at læse listerne $i$ avisen finder man lige saa mange tyske navne. Mærkeligt er det ogsaa, at man tør lade nordslesvigerne staa vagt, hvor kampen raser. Hvorfor trækker man saa os ikke ud af de forreste linjer, eller skal man blot være der for, at flokken kan smelte sammen og bringe endnu mere forbitrelse over hjemmene eller faa dem til at vaagne med fornyet kraft som før krigen. Har de herrer da endnu intet lært, eller føler de sig kun vel ved at være omgivet af utilfredse. Spørgsmaalene er nok til ingen nytte; men nu vil jeg afvente kompagniførerens resultat, og saa vil det følgende vise sig.

Jeg vil ikke glemme de mange, som under krigen har vist forstaaelse overfor vore vanskelige forhold deroppe og ikke mindst min kompagnifører; men ud over dem vil det i fremtiden gælde endnu mere for os derhjemme at slutte kreds og staa fast. Endnu er det krig, og jeg skal og vil som soldat gøre min pligt; men freden kommer engang, saa skal jeg være en fri mand og handle derefter.

Hilsen fra Thorvald. 


\section{Breve fra Thorvald Dau.}

(Udvalg ved Charles Borch.)

\section{Verdun.}

Paa vej til fronten den 2. juli 1916:

$\mathrm{Nu}$ er det snart to aar, siden jeg rejste til fronten første gang, og den almindelige mening blandt soldaterne er den samme nu som tidligere: vi er hjemme igen om seks uger.

Mens toget ruller ind mellem bjergene i Harzen bliver der saa stille, enhver vil gerne være lidt for sig selv, de taktfaste og monotone slag mod skinnerne faar nogle af kammeraterne til at falde i sovn, andre giver sig til at opfriske minderne fra den herlige tid i Osterode. Vi naar Gøttingen, og saa gaar turen gennem Weserbjergene til Limburg og derfra fortsættes langs med floden Lahn. Vi passerer Ems, og inden længe kører Toget over Rhinen.

- Den 12. om aftenen blev vi hældt ud af toget, og vi lejrede os for at afvente nærmere ordre. Den lille by, vi er komne til, har nu ligget skudt $i$ grus $i$ henved to aar. Der er kun nogle faa beboere tilbage, og de maa hver dag høre den døvende larm fra slagmarken omkring den store, nærliggende fæstning, som i øjeblikket danner basis for de haardeste kampe. Dag efter dag gaar store transporter af krigsmateriel gennem byen, og det er utroligt, hvad der er bleven befordret af artilleriammunition.

Vi fortsætter i bælgmørke og ad stærkt opkørte veje. Hist og her dukker et hus op, det ser ud, som skulde verden forgaa, og kanontordenen bliver ved $i$ det uendelige. Inde $\mathrm{i}$ en stor skov ser jeg for første gang lidt af stillingskrigen. Der er bygget barakker og dækninger som beskyttelse mod flyverne, der er 
gader med navne og vejvisere til lejrkommandanten. Nogle let saarede kommer gaaende ved stok, alvorsprægede ansigter, oversprøjtede med ler. Vor vej fører forbi en kirkegaard, den er stor og vokser stadig, og en uges tid senere ligger ogsaa en af mine kammerater begravet her.

Regnen tager til og sulten med. Vaade og stive som vi er, kryber vi sammen for at sove, men inden vi naar at falde til ro, bliver vi trommet sammen for at blive gjort bekendt med tjenestereglerne. Der er instruktion, eksersits og alt det der, akkurat som $i$ garnisonen. Om hverdagene er tjenesten haard, men rlen er værre om søndagen, hvor vi tager ud til øvelse med haandgranater, som gruppevis kastes ud af en smal grav. Det er en meget farlig manøvre, og den forekommer aldrig i "praksis». Et par gange gaar let godt, men saa er ulykken ogsaa over os. En af de otte haandgranater eksploderer for tidligt og nede $i$ graven ligger en kammerat med halvt afrevet hoved. Han er død og ved siden af ham ligger fire kammerater, jamrende og med en mængde saar. Sent om aftenen jordfæster vi den døde. Det øsregner, og præsten nøjes med en kort tale. Jeg forstaar ikke et muk af det hele, og undres slet ikke over, at en af kammeraterne finder paa at rabe, at Vor Herre har forladt os. Hvorfor dog al denne jammer. - Der er ved at komme ondt blod $i$ forsamlingen, en slaar sin bøsse itu, og en anden giver sig til at skælde en overjæger ud. Hvad jeg tænkte, kan jeg ikke skrive, og de andre tænkte som jeg. - I gaar vendte bataillonen tilbage fra stillingen, og der var bleven mange huller i rækkerne. De ligner næsten ikke mennesker, naar de kommer derude fra. Det kan vist ikke gentages ret ofte at sætte de samme tropper ind paa samme sted. 
Jeg bliver vækket ved et vældigt brag. Højt oppe i luften hører man en flyvemaskines motor snurre. Projektører sætter sig i bevægelse, og nogle batterier begynder at tordne. Nogle shrapneller eksploderer, men flyverne faar vi ikke øje paa. Der følger nu et par eksplosioner uden at gøre skade. Den brummende lyd forsvinder, og om lidt er alt roligt igen.

- Vi ligger ved en smalsporet krigsbane, hvor benzollokomotiver ustandseligt befordrer materiel ud i de forreste linjer. Hen ad morgenstunden kommer de tilbage, fuldt læssede af saarede; det er i reglen let saarede, da de haardt saarede vanskelig kan komme gennem spærreilden. Der er forøvrigt god udsigt heroppe fra højen, men hvor man vender sig hen, er der kun tarvelige rester fra fredens tid. Jorden er gennemfuret af skyttegrave, rodet op af granater og rundt om ligger store klumper af sammenfiltret pigtraad. Det er gamle stillinger, vi ligger $i$, fulde af minegange og al slags muldvarpearbejde.

Vort haab om at komme til en anden front er bleven tilintetgjort. Den 3. august blev vi pludselig alarmerede $\mathrm{i}$ vort kvarter i -; kompagni efter kompagni bliver stuvet sammen i lastautomobiler, og saa gaar det $i$ rivende fart mod Verdun. Det hedder sig, at vi kun skal bruges i yderste nødstilfælde, men en gammel soldat forstaar at vurdere en saadan melding. Der er slet ikke noget at tage fejl af, vor bataillon bliver gjort kampklar; der bliver uddelt haandgranater, signalpatroner og meget andet af det djævelskab.

- Jeg glemmer ikke min ankomst hertil. En fuldtræffer slog ned lige i nærheden af mig. Støn og skrig. Raab efter sanitetssoldater. Lidt længere fremme ligger en afreven fod, og et stykke derfra et 
par døde. Paa den modsatte skrænt er jorden rodet op i flere meters dybde. En gang imellem kommer en stafetløber over vejen - ingen opholder sig der længere end haardt nødvendigt - og henad eftermiddagen søger nogle mindre pionerafdelinger at bringe sveller herud, men artilleriet maa have bemærket det, thi svære granater hindrer dem stærkt. Vi ligger her paa den anden side og iagttager med spændt opmærksomhed det grusomme spil.

Daglig kræves der her svære tab, det er ikke krig, men simpelthen myrderi. Det er, som bliver man kun jaget herud for at vente paa døden, ude af stand til at værge for sig. Bøssen bruges næsten aldrig. Heller ikke af dem, der ligger i forreste linje. Det er ufatteligt, hvad der gaar til af artilleriammunition, der skydes hele Tiden og af og til sættes der ind med trommeild. For lidt siden saa jeg, hvorledes en tysk flyver blev skudt ned.

Hen ad eftermiddagen den 8 . august rygtedes det, at vi skulde afløse mandskabet $i$ forreste linje, og desværre talte rygtet kun sandt. Vi er allerede temmelig udmattede og stemningen alt andet end god. Ved midnatstide sætter gruppen sig i bevægelse, men det er vanskeligt at holde forbindelsen vedlige. Hvert øjeblik maa vi kaste os ned for at faa lidt dækning mod granatsplinterne, og der er ingen vej, ingen sti mere at holde sig til. Kun huller og gennemrodet jord. Det er et rent helvede. Utallige projektiler krydser her deres bane og fremkalder en oredøvende larm, ingen andre end dem, der har været herude, kan forestille sig al den elendighed. Af og til bliver der en kort, men saa meget mere uhyggelig pavse, i hvilken man hører infanteriilden i det fjerne, og ind imellem opfanger oret saarede og døende kammera- 
ters raab. Lyskugler og signalraketter, der taler til artilleriet, farer til vejrs og belyser omgivelserne med et skær, der faar en til at fare sammen. Uhyggeligt er det syn, det skarpe lys giver os lejlighed til at se i et kort og rædselsfuldt glimt. Faldne heste, stinkende, lemlæstede lig, som ingen tænker paa at grave ned; det vilde simpelthen være umuligt, de vilde ligesaa hurtigt blive væltet frem til overfladen af granaterne. - Her er banedæmningen, oplyser en i gruppen, saa ved vi det for en anden gang. Nogle jernbaneskinner, der ligger sammenkrøllede som sejlgarn, er det hele, der er tilovers af banen.

Det tager fire timer for os at naa frem til stillingen, nej ikke stillingen, men den linje, hvor stillingen skal være. Her ligger nogle udmattede soldater, som næppe har kræfter til at slæbe sig hjem, om de saa fik lov dertil. Endelig lykkes det at faa kompagniet lagt $i$ det rette afsnit, saa der er forbindelse til højre og venstre. Spaden og hakkerne kommer frem, men den tørre lerjord, blandet med kalk, giver kun ringe valuta for vort arbejue. Et klageraab bryder ind $i$ samme øjeblik, ilden sagtnes en smule: kammerat, kammerat, lyder en svag stemme lige i nærheden. Vi kravler hen mod stedet. Halvt begravet i lerjorden ligger en saaret, hans ben er brækket og lugter allerede. Det er umuligt at slukke hans tørst, men en slurk kan gøre underværker, og vi ofrer lidt af feltflaskens kostbare indhold. Intet vilde være os mere kært end at efterkomme hans onske om at hjælpe ham bort, men det er ikke vor opgave, og vi maa love ham at faa fat $i$ saniteterne, saa han kan komme bort endnu samme aften. Han har allerede ligget siden den - det er tre dage siden. Vi jævner jorden lidt og lægger ham tilrette paa en kappe. Tæt 
ved ligger en anden, ogsaa han har været halvt begravet. Det er galt med brystet, og tilmed er han saaret i den ene arm. Vi forbinder ham og lægger ham ved siden af hans lidelsesfælle, og samtidig gaar der bud til kompagniføreren. Da det begynder at lysne, tager ilden noget af, og vi vender tilbage til vor hule, hvorfra vi kan holde lidt udkig. Til venstre ligger en af de meget omtalte byer - det er dog kun navnet, der er tilbage. En enkelt bjælke betegner stedet, ellers er husene fuldstændigt blandede med den jord, de har staaet paa. Fremefter er der $\mathrm{k}$ un $60 \mathrm{~m}$ til franskmændene, og vi kan se enkelte af clem løbe omkring. Paa højre flanke har vi igen franskmænd, installerede i nogle sammenskudte værker. Den langvarige stilhed sætter lidt humør i os igen, og mens vagten holder udkig, haler vi andre mad op af randslen. Sulten er ikke saa stor som tørsten, men der maa holdes hus med det, der findes af vaade varer. Bare vi endda havde nok at drikke, eller havde vi blot en ordentlig stilling $i$ de to dage, vi skal være her. De to saarede er rolige, de er vel nok faldne i søvn.

Ved middagstid kommer nogle franske flyvere over vore linjer, ledsaget af en mængde shrapnelskyer; det er ikke let at ramme dem. Tjivtjang. Først enkelte skud, saa flere, tilsidst en hel kæde af artilleriild mod vor linje - jord og træstumper oversprøjter os en 3-4 gange, indtil vi bliver klar over, at vi maa længere ned, og hakkerne kommer igang igen. Pludselig gør en af kammeraterne en opdagelse. Hans hakke har aabnet for en hule, og gennem et hul saa stort som en næve lader vi en elektrisk lyskegle glide ind. Det er tydeligt, at hulen er stor, og nu bliver der arbejdet med feber paa at faa lavet 
en indgang. Men hvordan er dette gaaet for sig, har jorden sænket sig eller er det en af de store sprængringer, der har gravet hul her, hvem ved? Over os ligger et fire meter stærkt lerlag, og hvis ikke en af de store fyre sætter sig ovenpaa, kan lejligheden ikke trykkes sammen; der er plads til fire mand og udmærket læ under den morderiske artilleriild, som dagen igennem indtræffer $\mathbf{i}$ bestemte perioder. De første lyskugler farer $i$ vejret og snart lægger mørket sig over jorden. Lytteposterne kryber frem for at afværge overraskelser. Tiden snegler sig afsted, hare vi snart kunde faa kaffe, den sidste slurk er (Irukket, og klokken bliver baade 1 og 2 . Fra venstre fløj gøres der tegn til, at kaffen er i nærheden, og som et lyn farer en af os derhen med et kogekar. Efter et kvarter vender han tilbage. Hvor meget fik du, sporges der fra alle sider. For sent lyder det trøstesløse svar. Fordelingen er vanskelig, og til os bliver der intet. Saa maa vi vente, til vi bliver afløst den følgende aften, og det eneste, vi kan gøre, er at sidde stille, og saa vidt muligt sove os fra det. Vor saarede kammerat ved siden af begynder igen at klage sig, og jeg kravler hen til ham. Man er ikke godt tilmode i et saadant øjeblik, selv er man tørstig og flasken tom. Han mener, at hans flaske maa ligge et sted, og at den er halvfyldt med kaffe. Jeg giver mig i lag med at søge efter den mellem de store lerklumper. Der ligger en flaske, den er tom som min egen. De svage hænder rækkes ud efter den: Lad mig prøve. Forsigtigt fører han den til munden, men resultatet er negativt. Hvornaar kommer der hjæIp, lyder hans trøstesløse spørgsmaal. Næste nat - nej, saa skyd mig hellere. - Du maa holde nd; han tier, og jeg river mig løs. Natten forløber ellers 
temmelig rolig, kun til højre for os blusser infanterii]den op. Den paafølgende morgen er himlen skyet, maaske giver det sig til at regne. Et teltplan spæncles ud for at samle vand til at fugte læberne med. Kommer der lidt slim i munden, er man næsten ikke istand til at synke, og dagen tilbringes $i$ halvsløv tilstand; næsten uden at der veksles et ord. Og siges der noget, er det kun forbitrede, halvkvalte udbrud. Det bliver ikke til noget med regnen, men med aftenens frembrud dukker haabet om afløsning op. For anden gang kryber lytteposterne frem. Denne gang bliver klokken tre, inden vi hører noget, men det er ikke afløsning - kun kaffe. Med nød og næppe har vi reddet en feltflaske fuld til vor gruppe; de stakkels kaffebærere er bleven ramt af 2 fuldtræffere, og størsteparten af kafifen spildt undervejs; paa den maade forøges tørsten kun endnu mere. Næste formiddag er endnu ikke tilende, og vor flaske er allerede tom igen. Den ene efter den anden bliver saa svag paa benene, at det næsten er umuligt at staa oprejst. Kommer der ingen afløsning inat, bliver vi simpelthen ude af stand til at slæbe os hjem. Hen paa eftermiddagen sætter det franske artilleri ind med en rasende ild. Halvt i døs venter vi paa, hvad der vil ske. Pludselig tier artilleriet og afløses af en knitrende lyd fra de tyske bøsser tilhøjre. Franskmændene angriber, raaber vagten. Det koster kræfter at komme paa benene. Ganske rigtigt, tilhøjre arbejder franskmændene sig frem. Meldinger og befalinger løber gennem skyttelinjen, mens ilden tager til. Ogsaa lige foran os begynder Franskmændene at røre paa sig. Det ser ud til, at de stadig skaffer reserver til højre. Flere gange farer tyske fuldtræffere ned $i$ de franske grupper. Hvad der er sket paa højre fløj, bliver vi 
ikke rigtig klog paa, men efter en times tid lægger ilden sig, og der er ingen, der kan faa øje paa franske bevægelser mere. Helt udmattede lægger vi os ned, mens mørket falder paa. En ordonnans kommer med de nødvendige instrukser til afsløsning, i nat bliver det saa endelig til alvor. Det sætter kræfter i os igen. Vi laver et par baarer af bøsser og teltplan, og kompagniforeren bestemmer mandskab til at bær staklerne; næsten alle maa hjælpe, thi der er ogsaa en del af vore egne, der er saaret. Langt over midnat kommer afløsningen, friske tropper, som kommer hertil for første gang, og de spørger noget forundret, om dette er vor stilling. Har vejen herud ikke været tung, saa bliver tilbagevejen det; udmattede er vi, og saa den byrde at transportere de saarede; hver bevægelse volder dem smerte. Det er en lang og trang vej til reservestillingen, og vi naar ikke derhen uden tab. Jeg har aldrig været saa træt, vi maa næsten slæbe os tilbage - det er, som havde man jernklumper ved benene. Her er vand, raaber en; ingen kan se, hvad det er, der drikkes. Det lugter efter lig $i$ nærheden, og vandet smager forfærdeligt, men drikkes alligevel. Kompagniet er fuldstændig i opløsning. enhver arbejder sig afsted, saa godt han kan. Henad morgenstunden er jeg sammen med en anden naaet udenfor artilleriets rækkevidde, og snart finder jeg et sted, jeg kender. Ved et holdested for jernbanen staar en soldat, og han har varm kaffe. Vi er som foryngede, og hen paa formiddagen har vi naaet kompagniets samlingssted; her er vi - alle dem, der har beholdt hele lemmer. Vi har alle forandret os i de otte dage, og enkelte er slet ikke til at kende igen.

Der forestaar os igen en drøj tur, og da vi naar vort bestemmelsessted næste dags middag, er kom- 
pagniet atter skrumpet lidt ind. Nogle er bleven liggende undervejs af udmattelse, og hen paa eftermiddagen bliver vi saa læssede paa jernbane. Turen gaar gennem Luksemborg, hvor kornet staar i skok og de fredelige landsbyer danner en skrigende modsætning til kampladsen derude. Det gaar nu til en af de gamle stillinger, hvor de nu har ligget overfor hinanden $i$ aarevis. Det forekommer mig, at vi stadig zaar i rundkreds, vejen er ikke til at blive klog paa. Omsider naar vi en flere hundrede meter lang tunnel, der er gravet gennem et lille bjerg, og vi er dermed kommet helt ind paa livet af modstanderen. Inde $\mathrm{i}$ tunnelen besørger et lille elektricitetsværk lys til "muldvarpene«. Der skal sprænges i morgenstunden, og vi faar orlre til at blive i tunnelen saalænge. - Jeg maa have sovet meget haardt, sprængningen er forbi, og jeg har ikke mærket spor til den, skønt der er brugt flere hundrede centner sprængstof, og hele bjerget har rystet, saa nogle af kammeraterne er drattet om.

Livet her i skyttegraven begynder at tiltale mig, naturligvis kun fra det standpunkt, at man skal være med i krigsspillet. I hvert fald er dette her som dag mod nat $i$ forhold til det, vi for var med til. Sammen med et par kammerater er jeg bleven fyldt ned $i$ en hule, hvor vi fører en tilværelse, som mangen en maaske vil misunde os for. Vor hule ligger godt gemt i en labyrinth af gange, som kun en stedkendt hitter ud af. Indgangen til hulen er kun en halv meter høj og fører temmelig stejlt nedefter, saa vi altid maa kravle herned paa alle fire og med bagbenene først. Hernede kan vi saamænd staa ligesaa meget vi vil, men ellers er der bænke nok, et bord er der ogsaa, en kakkelovi og forresten en mangde hylder 
foruden vor seng, som er lavet til af en hylde, der er overspændt med hønsetraad. Væggene er beklædt med brædder og loftet stivet af med svære egeplanker, som igen er beklædt med jernplader. Lidt fugtig er lejligheden, men man maa jo betænke, at vi har fem meter jord over os. Rundt omkring er der ophængt konservesdaaser til at opfange draaberne, der siver igennem. Den elektriske pære vil ikke rigtig brænde, men $i$ stedet for har vi til stadighed en karbidlampe under blus, og over den har vi anbragt et kogekar med kaffe, saa vi altid kan faa noget varmt at drikke. Et kvarters gang herfra har pionererne bygget et vandværk, men det tilfredsstiller os ikke, og vi maa anvende en del sparsommelighed med vandet, saa vi kan blive vasket i det mindste een gang om dagen.

Det kunde næsten være nødvendigt at bemærke, at der ogsaa bliver skudt her engang imellem. I nat skal jeg bl. a. paa arbejde paa en fremdreven minegang. Vi lever saamænd $i$ god forstaaelse med franskmændene, og der bliver ikke taget megen notits af skydningen, der som oftest foregaar til bestemte tider om dagen og paa bestemte punkter, saa vi altid veed, hvad vi har at rette os efter. I øjeblikket er de forresten ved at bombardere os; det dundrer ordentlig, og lufttrykket har flere gange pustet vore karbidlamper ud, men ellers kan de ikke gøre os nogen skade hernede. Det er svære miner, de sender - artilleriet spiller kun en ringe rolle her, hvor vi ligger saa tæt paa hinanden - og saa bruges der forresten "karduser", hvorfra minerne udskydes i en kort og stejl bane, saa de kan gaa ned i bunden af graven. De demolerer selvfølgelig gravene fra tid til anden og giver os arbejde med at reparere; men vore huler 
tager ingen skade. Den eneste fare, vi er udsat for hernede, er egentlig kun den gas, der udstrømmer ved minesprængningerne. I de mod flere franske linjer fremdrevne minegange, ogsaa kaldet "sapper", foretages der af og til sprængninger, baade tragt- og kvæstesprængninger. Ved en kvæstesprængning søger man at opnaa, at modstanderens lobegrave bliver trykket sammen. Den ved en saadan sprængning udviklede gas naar ikke altid op over jorden, og søger saa andre veje, og den kan saaledes overvælde een, inden man mærker det. Af den grund er der i hver hule altid en vagt, som hurtigt kan alarmere mandskabet med redningsapparater. Til beskyttelse mod gasgranaterne eller andre gasangreb er vi desuden forsynet med gasmaske, men i kampgraven og $i$ de fremdrevne minegange er det haandgranaten, der har ordet.

Her i Argonnerne er det nu ikke saa lidt bedre end $i$ afsnittet Fleury-Thiaumont. Forleden saa jeg en artikel fra en krigskorrespondent om byen Fleury. De forskellige generalstabsberetninger beskæftiger sig ogsaa stærkt med byen, der tales om gader og bydele, huse og en jernbanegaard. Jeg gad nok vide, hvad de egentlig forestiller sig, om de tror, byen stadig er den samme som i fredstid - den eksisterer ikke mere. Hvad far spørger om gennem det medsendte avisudklip, er her ingen hemmelighed mere, jeg tror heller ikke, fredstanken har vanskeligt ved at passere censuren fra fronten. Jeg kunde saamænd godt fortælle en del betegnende træk. Selv om en vis krigstræthed gør sig gældende, vilde det dog nok være helt forkert at antage, at nu stod ententen overfor en knækket modstander. Jeg tror ikke, at der kan ske betydningsfulde frontforandringer $i$ vest, 
forudsat at der er tilstrækkelige reserver. Værre ser det nok ud for østerrigerne; der tales saa smaat om, at de ikke kan mere.

Vi fordriver tiden med natarbejde i denne tid; ved morkets frembrud spaserer vor lille gruppe, forsynet med skovl og hakke, til forreste kampgrav, og herfra videre gennem en minegang til en stor sprængtragt. Hvad vi laver her, kommer selvfølgelig ingen ved, men det er interessant at mærke, hvorledes de to modstandere saa at sige søger at skubbe hinanden bort. Mens vi som oftest arbejder over jorden, besørger pionererne den underjordiske del ved at føre minegange helt ned under de franske stillinger. Elektriske, fuldstændig lydløse motorer fører frisk luft ind, mens den løshakkede jord bæres ud i smaa sandsække. I et hjørne sidder lytteren med et telefonapparat, som hjælper ham paa spor efter modstanderens arbejde. Sprængninger er her dagligdags begivenheder, og det vilde være uhyggeligt, om man ikke vidste, at der kun sprængtes til bestemte tider om dagen. Jeg holder $i$ hvert fald nok af den orden, og tænker paa den, hver gang de kommer slæbende med dynamitten. Helt nemt er det ikke at arbejde i mørke, og saa har man end ikke lov til at give sine tanker frit løb i skældsord. Franskmanden vilde selvfølgelig more sig med at krydre dem endnu mere. Vi lader hinanden dog for det meste $i$ fred. Det kunde jo ske, at der kom nogle haandgranater over til os, naar de mærkede, at vi blev alt for ivrige med at grave. I stedet for at begynde med større slagsmaal kyler vi nogle klumper jord eller sten efter dem. Det lader til, at de forstaar denne advarsel, og efter dette har vi kunnet arbejde i fred. 


\section{I bjergene.}

- Paa den ene side svidende røg og paa den anden bidende kulde sidder jeg heroppe i $1242 \mathrm{~m}$ højde, og mens rimen fra træerne flyver mig om ørerne, forsøger jeg at sende eder et par ord. For ca. 14 dage siden forsvandt vi ind $i$ bjergene, og efter haanden som vi kom til vejrs, dukkede det smukkeste panorama op. Fra $2000 \mathrm{~m}$ højde kan man se ned over sletterne, hvor Rumænerne er i virksomhed, og det er meningen, at vi skal afskære dem fra tilbagetog gennem passet ved en forestaaende offensiv. Henimod aften kom vi i berøring med dem, og efter nogle dages kampe blev de trængt tilbage. Nede i landsbyen ser det sørgeligt ud; jeg talte 30 døde heste paa et sted. Nu sidder Rumænerne $i$ den ene ende af passet og tyskerne $i$ den anden. I morges var jeg med til at rydde en høj, og en Rumæner var da saa elskværdig at skyde mig en kugle gennem »Chakoen" - et strejfskud $5 \mathrm{~cm}$ over højre ore, et skud af samme siags maa de godt give mig igen, naar tiden er inde.

Krigen i bjergene er et kapitel for sig. Her er det ikke infanteri-masser, som styrter los for at tage stillingen i storm, efter at artilleriet har knækket modstanderen ved bombardement. Nej, her ligger hver for sig paa jagt efter sit bytte, bag en klippeblok eller et træ. Det enkelte skud er mere farligt end infanteriets masseild dernede i sletten. Fire mand, deriblandt jeg, blev som spejdere sendt forud for at sondere, hvad der var paa højen. En skovbevokset bjergkam fører fra vor yderste vagtpost mod fjenden. Den fjendtlige høj vender en stejl bredside imod os. Vi tager et lílle pusterum, og dækket af træerne spejder vi efter Rumænerne. Det er en let sag at skjule sig heroppe og ganske roligt lade os komme frem. 
saa hvert skud kan blive en træffer. Vi kravler videre, men pludselig dukker foran mig i ca. $30 \mathrm{~m}$ afstand oppe paa højen en skarp trekant op - det er en rumænsk hue. Jeg giver de andre advarselstegn og kryber selv om bag et træ. Det er en ubehagelig stilling her paa skraaningen, og selv kan man intet se. Jeg rejser mig op for at faa oje paa noget mer, men i samme øjeblik faar jeg et stærkt slag i hovedet og triller nogle meter ned, og en kammerat faar samme henfart. Maaske er han ramt af samme kugle. Det bløder stærkt, og andre projektiler suser om ørerne paa mig, mens jeg skynder mig i dækning; bag en klippeblok sidder vor afdeling, og saniteterne forbinder mig. Jeg har hovedpine, ellers fejler jeg ikke noget, men det blev en haard dag for mange. Jeg klatrer den besværlige vej tilbage, og er glad for at kunne hjælpe mig selv i god sikkerhed mellem vore vagtposter. Hos stabslægen faar jeg forbindingen efterset $\mathrm{og}$ han forsyner mig med et mærke: "marchfähig“. Sammen med et par syge vandrer jeg nu afsted nedad, fulgt af misundelige blikke. Ved foden af bjerget kreperer en-shrapnell over hovedet paa os, det er rumænernes sidste hilsen.

- En rumænsk bondegaard, som vi fandt den her, er en omstændelig historie. Rundt om $i$ gaardspladsen ligger en mængde huse, beboelsesrum, køkken, svinestald, hønsehus, lade osv., alt hver for sig. Deres vogne og redskaber, klædedragt og alt andet er hjemmelavede ting, og det er et morsomt syn, naar saadan en kvindeklædt pisang kommer ned ad gaden, svingende pisken og raabende sit tjia sau til et par køer, der langsomt, men sikkert følger efter med en tungt lasset vogn. Et par aftener tog jeg sprogundervisning ude i køkkenet hos Savinne (husmode- 
ren), naar kun kogte "marmelika«. I skulde bare have set køkkenet, en firkantet kasse, sat op af raat tilhuggede træstammer. Nogle bænke og et bord og ved siden af et aabent ildsted. Indad Døren kiggede afvekslende svin og kalve, naar de kom forbi paa deres spaseretur. Røgen sved i øjnene; mens jeg pegede paa de forskellige sager og savinne fortalte mig, hvad de hed. Jeg noterede det $\mathrm{i}$ min lommebog - nogle forfærdelige ord - og naar djort (manden i huset) kom hjem, forsøgte jeg ved hjælp af mit leksikon at tale rumænsk med ham til moro for os allesammen.

Den 12. september havde vi besøg af vor kommanderende general Kraft von Delmenringen. For kampen ved Verdun havde han faaet ordenen "Pour le mérite«. Han holdt en.tale til os. De skulde nok faa at føle, at vi var soldater, der duede noget, og bedre end det andet pak, de ellers var vante til at slaas med, men iøvrigt fortalte han ogsaa, at det var forbudt at tale nedsættende om østerrigerne. Flere gange har jeg nu set, hvor nødvendig denne ordre har været, og der er endda dem, der mener, at tyskerne bedre kunde have klaret krigen helt alene. Jeg synes ogsaa, at de nærmest kun staar $i$ vejen, hvor vi kommer.

- Den 21. gik vi tilbage over Alvins Mühlenbach til den store landsby Roho, (helt igennem rumænsk), og sammen med en kammerat kravlede jeg ind hos en bonde, som tog meget venligt imod os, vistnok mest af angst. Han vartede op med alt muligt, og min mave bestod sin prøve paa at være $i$ orden igen. Ved ankomsten serverede han vindruer, blommer og brød, en time senere kartofler og tykmælk. Derefter kom han med ferskner, og inden vi gik til køjs, 
skulde vi have en omgang ungarvin. Af en ejendommelig stor trækrukke skænkede han den sure druesaft, holdt en lang tale med allehaande fagter, som jeg ikke forstod et muk af, drak først selv et glas, og saa kom turen til os. Næste morgen skulde vi have vin igen, derefter mødte han med varm mælk, stuvet kaal, vindruer og bred.

Vor vej er langsom og besværlig. Adskillige af vore bagagevogne styrter ned, naar vi forsøger at bane vej paa stejle skrænter og mellem store sten. Uden at mærke noget til rumænerne fortsætter vi den 25. langs med grænsen, men kl. 11 erklærer vor fører, en ungarer, at han ikke kan finde vej mere i morket. Det fryser heroppe i 2200 meters højde, og det koster møje at faa ild i nogle grønne buske for at tilvejebringe lidt varme. Den 26. om morgenen nærmer vi os maalet; vi naar over en bjergkam og herfra har vi clen dejligste udsigt over slettelandet. Det titter frem gennem hvide skyer under os. Der er liv og røre dernede; langs med floden kører et tog, og paa landevejen marcherer tropper. Det er alt saa smaat heroppe fra, saa det kun kan ses tydeligt gennem en kikkert. Efterhaanden som vi kommer ned, afløses de smaa buske ved graner, og saa møder vi græsgange med store faareflokke for tilsidst at havne $i$ en gammel bøgeskov, hvor træerne ligger hulter til bulter. Der fortælles, at kun faarehyrderne kan slippe igennem her. - Længe varer det ikke, før en stærk geværild forkynder, at vi har faaet føling med modstanderen. Den 29. rykker vi lidt frem, men der kæmpes haardt for at dæmme op mod den tilbagevendende rumæner. Den 30. sidder vi med hele staben paa en bjergspids og maa forsvare os til alle sider, og den næste morgen bliver jeg sendt ud som patrulje for 
at reparere telefonledningerne, som rumænerne har klippet. over om natten. Hen paa eftermiddagen bliver vi sendt ud for at finde en vej op $i$ bjergene paa den anden side passet; vi finder ogsaa en, men kommer i klammeri med rumænerne, og næste dags aften, ra vi er kommen til bestemmelsesstedet, bliver der igen uro, rumænerne begynder at skyde. Den 6. oktober kom saa den dag, hvor jeg kunde forlade den anstrengende tilværelse deroppe. Nu venter vi bare paa, at et tog skal komme og tage os med til Tyskland.

- Orden er en svaghed hernede. Hermannsstadt havde, da krigen brød ud med Rumænien, en garnison paa 75,000 mand, som hals over hoved drog ud af byen, og bagefter fulgte civilbefolkningen. Kun een officer med 300 mand, foruden nogle faa politiembedsmænd blev tilbage, rumænerne kunde altsaa, dersom de havde haft hovedet paa rette sted, have haft let spil, men de naaede i løbet af tre uger kun at faa 1 patrulje frem til byens banegaard, og da saa de tyske tropper kom, led de hurtigt nederlag. Daarlige førere maa være skyld heri; den rumænske soldat har vist sig tapper, hvor jeg har været i berøring med ham. Han er ikke af den slags, der strækker hænderne i vejret eller stikker af, saasnart han ser en bøssepibe rettet imod sig.

- Der fortælles af og til, at Danmark har erklæret Tyskland krig. Jeg kan dog ikke faa mig selv til at tro det. Skulde det virkelig en gang ske, saa bliv endelig hjemme, indtil I bliver jaget ud eller faar ordre til at drage bort. Det er det eneste raad, jeg kan give Eder efter at have set, hvor mange der har faaet deres hjem lagt $i$ ruin, fordi de flygtede for tidligt. I kan vel forstaa, at man bliver urolig, naar alle- 
haande rygter naar herud, og man nu paany har været vidne til krigen paa en egn, hvor folk er bleven overrasket og i største hast er løbet fra hus og hjem. Jeg talte i gaar med en mand, som kørte herfra i en godsvogn sammen med byens borgmester og en rigsdagsmand. De var 52 mand i vognen; han havde haft 2. kl. billet, borgmesteren og rigsdagsmanden 1 . kl. Der er ellers foregaaet underlige ting hernede, som jeg vil fortælle om en anden gang.

- Her udkommer en lille avis "Siebenbürger Tageblatt«, store ting bringer den ikke, men en mængde fortællinger om rumænernes holdning, mens de var her i omegnen, fylder godt op. Der bliver naturligvis ikke fortalt milde historier om dem, og man kan vel heller ikke paastaa, at de har opført sig som engle, men værre end de andre er de saamænd ikke. Plyndrede huse og strenge forordninger over for befolkningen for at forebygge spionage kan man finde paa enhver krigsskueplads. De fuldstændig overrumplede beboere skælder selvfølgelig ud paa rumænerne, man skulde ellers tro, der havde været tid nok for militæret til at belave sig paa et saadant overfald, og saa var det jo ikke bleven til noget af betydning med rumænernes famlende forsøg paa at trænge frem i Siebenbürgen. Det skal aldeles ikke være et forsvar for rumænerne, jeg skriver her. Allerhelst vilde jeg lade dette pak passe sig selv og være blandt folk derhjemme, som man har en smule tilfælles med.

Det er ikke altid lige let at faa tiden til at gaa her, og man er selvfølgelig for doven til at bestille noget, men det volder nu ikke stort besvær at slippe bort, hvor vi er saa mange og den rigtige kontrol mangler. Driveriet indledes sædvanlig med et par 
raske spring om et hushjørne eller en halv times venten bag en busk, og ved en saadan manøvre slap jeg ogsaa ud i dag og havnede omsider paa torvet, hvor der var fuldt af mennesker. Sakserne stikker mindst af fra de mennesker, vi er vante til at se, men flere hundrede aar er gaaet, siden de forlod deres fædreland for her at skabe sig et nyt, og den tid har ogsaa været lang nok for dem til at optage lidt af landets sæder og skikke. Selv om de fleste kan tale baade ungarsk og rumænsk, bruger de dog alle indbyrdes deres eget modersmaal, og man kan jo kun rose dem for, at de holder fast ved det. Paa landbrugets omraade er de vel nok de mest fremragende, selv om det ikke har noget med saksisk landbrug at gore. Som regel bor de $\mathrm{i}$ byer for sig, men her paa markedet holder de nu i de lange rakker sammen med ungarer og rumænere, som det nu tilfældigt har truffet sig. Enkelte køretøjer er forspændt med heste, men den langt overvejende del maa nøjes med et par køer, okser eller ogsaa bøfler, og stor ulejlighed har de ikke med et klovdyrs seletøj; dyret faar kun hængt en slags aag om halsen, og dette er igen fastg.jort ved vognstangen. - Omsætningen af pengemidler volder en del besvær her paa torvet, idet der betales baade med tyske og østerrig-ungarske penge, og vekselmønt er der ikke megen af, men folk hjælper sig saa ved at rive 2 -krone-sedlerne igennem, og paa den maade fremkommer der baade krone- og 50-heller-sedler. Har man til eksempel købt for en krone og betaler med en mark, saaledes at man skal have 40 heller tilbage, parterer sælgeren ganske roligt en 2-krone-seddel til 50-heller-sedler og leverer den ene lap som vekselmønt. De 10 heller, der bliver imellem, jævner vi ved hjælp af syv penning. Det er 
en noget indviklet metode, og ikke saa lidt komisk virker det, naar man faar en del af de iturevne sedler.

- Nu har jeg været i krig i næsten tre aar. Først i Polen, saa i Frankrig, siden mod Rumænien. At jeg ogsaa skulde komme i strid med ungarerne, havde I nok ikke ventet. Men hor nu: Ungarerne og forresten østrigerne med er noget pak, siger tyskerne. De faar skyld for alt, som ikke lykkes eller ikke er, som det skal være. Egensindige er de ogsaa. Tænk, at de har forbudt at udfore levnedsmidler fra deres hellige land. Vist er det ingen hemmelighed, at Ungarn ikke under sine kampfæller noget, men at de ogsaa udvider bestemmelsen til kampfronten i fjendeland, fik jeg først at føle for nogle dage siden. De to gange, jeg har været i Runınien med slagtekvæg, har jeg nok lagt mærke til, at vi gjorde længere ophold ved grænsestationen, og at ungarerne ikke rigtig holdt af min ladning. Forleden fik jeg klarhed over dette forhold. En vagtmester kom og fortalte, at ungarerne ikke vilde tillade, at vi sendte mere kvæg over grænsen. Hvad saa, lød mit spørgsmaal. Ja, nu maa vi forsøge at smugle det over; det gaar los i aften. Om jeg kendte landevejen til Predeal. Helt sikker var jeg ikke, men for ikke at blive kasseret som transportfører af den grund, sagde jeg ja. Saa fortalte han, at transporten blev paa 100 stykker kvæg, at jeg fik 8 ledsagere med. At det vilde blive en interessant tur, var vi alle enige om. Humøret var godt, og ingen tænkte paa, at nattehvilen maatte vige for den $24 \mathrm{klm}$. lange vej. Det er ikke hver dag, der bliver givet ordre til at snyde ungarerne. Kl. 8 aabnes dørene, og kreaturerne bliver sluppet løs, meget utilfredse med den utidige alarmering. Turen 
gaar uden om byen, og saa længe der er hegn paa begge sider af vejen, gaar det udmærket, men snart faar vi mas nok med at holde sammen paa selskabet. Et par mand er stadig paa jagt efter en desertør, men jeg gaar foran og viser vej. Efter en timestid kommer en mand hæsblæsende og fortæller, at et dyr er stukket af og ikke er til at finde igen, og kort efter meldes tabet af nummer to. Hvad skal det blive til, naar vi først kommer ind $\mathbf{i}$ bjergene, hvor vejen snor sig, og der er meget, som kan vildlede. Blive staaende kan vi ikke, saa løber de allesammen, men jeg vidste paa den anden side, at inspektøren regnede med tab. Saa blev det besluttet at drive kvæget ind paa en indhegnet plads i nærheden af banegaarden, hvor vi før har forladt kvæget. Jeg var glad, at vi var naaede saa vidt og fik nu ved telefonisk forespørgsel besked om, at vi skulde vente der til næste morgen og, saasnart det blev lyst, fortsætte sammen med en anden transport. Mens vi drev kvæget ind $i$ et skur, og jeg var $\mathbf{i}$ færd med at tælle - der manglede stadig to - kom den anden transport, som ganske paa samme maatte have mistet et par dyr. Senere fik jeg at vide, at de manglende dyr var bleven solgt til rumænske jøder, og at en del fede dyr var byttet med ringere og pengene fordelt mellem transportsoldaterne. Vi forsøgte saa at finde et natteleje, men jeg var ikke faldet til ro endnu i en gammel kasse, da vagten raabte, at kvæget var begyndt at spasere gennem den skrøbelige trævæg. Saa maatte vi ud igen for at finde de manglende Dyr. Næste morgen madte vagtmesteren i egen person for at overtage transporten, men det gik snart op for ham, at vi vilde miste alt, dersom vi fortsatte paa den maade. Vi naaede omsider passet og havde arbejde 
nok med at holde kvæget sammen til trods for, at det var lyst. Ved middagstid forer vejen opad i zik-zaklinje; vi er ikke langt fra grænsen. Vagtmesteren er kørt forud og kommer nu tilbage med besked om, at vi skal vente, til det bliver mørkt og drive kvæget tilbage $i$ en nærliggende dal saalænge. I ventetiden kørte jeg sammen med vagtmesteren over grænsen for at gøre staldene klar til modtagelsen, og jeg kom der paa det rene med, at det skulde gaa meget mærkeligt til, hvis ungarerne ikke mærkede noget til vort forehavende. Ved grænsen staar en gendarm og reviderer nogle automobiler, og et stykke derfra en lysk vagtpost, ligeledes reviderende. Tyskerne har nemlig forbudt udførsel af forskellige ting fra Rumænien. Vi finder snart plads i nogle træbarakker, som er bleven sat op til artilleriets og trænets heste, mens der blev kæmpet her i nærheden. Selve byen danner et trist billede i modsætning til de storslaaede omgivelser. Ikke et hus er bleven skaanet, kun ganske faa af indvaanerne er vendt tilbage, men byen er selvfølgelig ikke saa medtaget som mange af dem, jeg har set paa vestfronten. De stakkels mennesker, som saadan jages bort og kun finder lidt eller ingenting af deres hjem, naar de vender tilbage. Jeg kommer forbi en lille hytte, en granat har revet taget af det ene hjorne. Vinden piber gennem de ituslaaede ruder. Ogsaa doren mangler, den har en frysende soldat brugt til brændsel. I aabningen er en gammel kone og en dreng i færd med at slæbe et komfur ind i huset. Det gaar kun langsomt over murbrokker og andet skrammel. Jeg nærmer mig de to hjemvendte flygtninger og forsøger at faa en samtale i gang, men de forstaar mig ikke, og den gamle ser paa mig med et par forpinte øjne. Jeg vilde gerne have trøstet 
dem lidt $i$ deres nød, men sproget mangler, og $i$ stedet for hjælper jeg dem saa komfuret paa plads og forsvinder. Vagtmesteren har imens været paa jagt efter middagsmad, og det er lykkedes ham at kapre en portion "dörrgemüse«, tørrede grøntsager eller "traadforhindringer", som denne ret kaldes $\mathrm{i}$ soldatersproget, men det smager udmærket, og saa giver vi os i lag med at søge efter snigveje, for at kreaturerne i skumringen kan smugles over grænsen. Vi har knap nok begyndt smuglerfærden, før en ungarsk patrulje paa otte mand opdager os og vil lægge beslag paa kreaturerne. Først kom der allehaande kønne ord fra vor side: det var rumænsk kvæg, som skulde føres tilbage. Da de ikke vilde gaa ind paa det, begyndte vi at skælde ud, og da de vilde have kvæget, sagde vi, at de skulde prøve paa det. Nu var det haabløst at faa gennemført smuglingen, men det vilde være altfor stor skam, hvis de fik lov til at tage dem fra os. Patruljeføreren truede med at arrestere vagtmesteren, dersom han ikke adlad, hvortil han svarede, at den første, der rørte ham, vilde blive slaaet til jorden. Saa begyndte vi at drive kvæget tilbage, forfulgt af gendarmerne, og næste morgen finder vi den anden transport, som flere gange har været $i$ ordstrid med gendarmerne, hvis styrke nu er steget til 25. De forsøger at stoppe dyrene med deres bøsser, men vore stokke virker bedst, og gendarmerne maa opgive. Da vi naar vejen, der forer bort fra Kronstadt, driver vi i en fart kvæget derind for at undgaa toldstedet. Gendarmene faar travlt, og kampen begynder paany. Denne gang gør de energisk modstand og truer med at skyde. En gendarm, der vil støde med bajonetten, faar klø, og trækker sig tilbage; en anden springer ind paa mig, slaar sikringen 
fra sin bøsse og sætter bajonetten til mit bryst. Hvad der derefter skete, foregik hurtigere, end jeg kan beskrive det. Med venstre haand griber jeg fat $\mathbf{i}$ bøssen, og tvinger den til side, mens jeg med højre haand svinger stokken ned over hans arm, og bossen er min. Ogsaa de andre er geraadet i nævekamp, og en af vore folk fik et lettere stik i siden. Vi synes at have overtaget, men saa kommer andre gendarmer til; hver med bøssen færdig til skud gaar de imod os i en regelret skyttekæde. Nu maa hovedparten af kreaturerne alligevel den vej, ungarerne vil, men alt imens gaar der bud om hjælp, og svendene fra slagtehuset kommer os imøde nogle faa klm udenfor Kronstadt, hver med sin bøsse. Det hjalp. Stadig forfulgt, men uden hindringer bringer vi transporten tilbage til den stald, vi havde forladt dagen før. Kvæget blev saa slagtet, kødet pakket i tønder i jernbanevogne og omgivet af halm og paa den maade smuglet ind i Rumænien, men ved ankomsten dertil var det raaddent.

- Efter at have holdt os rejsefærdig nogle dage, blev vi langt om længe fragtet til Insuratzi, og det ser ud til, at vi foreløbig skal blive her. Der er ikke ret meget mandskab til raadighed, og som følge deraf har vi megen vagttjeneste, hvor vi foretager paseftersyn. Det morsomste er, at de fleste, der rejser til og fra byen, har pas, som er udstedt paa tyrkisk eller bulgarsk, og da vi ikke forstaar en stavelse af det, der staar der, nøjes vi med at lade, som om vi forstod os paa snirklerne, og de faar alle lov til at passere. Sidst jeg var paa vagt, fik vi forstærkning, fordi der var kommet en bulgarsk kolonne efter halm og vilde overnatte her. Forstærkningstropperne skulde overvaage, at bulgarerne ikke hentede kreaturerne om natten. Bulgaren gælder for at være en dygtig 
soldat, men han stjæler og røver alt det, han kan overkomme. Det er vel en medfødt egenskab hernede paa Balkan. - I et gammelt bageri, der er indrettet som arrestlokale, sidder en zigøjner, som blev nappet ved et faaretyveri, og i eftermiddag forsøgte han at hænge sig. Hvorfor ved jeg ikke. Nu har vi ham herinde $i$ vagtstuen, hvor han sidder $i$ et hjørne og klynker. Jeg forsøgte at opmuntre ham med en cigar og et glas vin, men han har ikke appetit til nogen af delene. Vinen er sur og noget slemt stads, men alligevel bedre end det daarlige drikkevand her. Det kan ogsaa hænde, at en og anden af soldaterne søger trøsten i denne vin, og saa vandrer han i kachotten. I gaar saa jeg, hvorledes rumænerne begraver deres døde. Liget bæres fuldt paaklædt og aabent fra hjemmet til graven, og foran ligtoget bæres gravkorset og et ungt træ, og til begge dele er fastgjort en hvid dug. Ved graven foregaar de mærkeligste ceremonier, inden kisten lukkes for den døde, der faar penge, mad og vin med paa rejsen. Følget istemmer skrigende klageraab, kysser den dødes haand, og langt om længe sænkes kisten i jorden. Forresten kan man hver morgen se, hvorledes slægtninge bringer fødevarer eller ild til deres kirkegaard, hvorfra stadig den samme klagemelodi lyder som ved begravelsen.

\section{Skyttegraven ved Thiaucourt,}

\section{i August 1917.}

Jeg havde dog ikke troet, at far alligevel var bleven indkaldt, maaske det dog kan blive anderledes, naar han har saa mange paa sin side, som gerne vil have ham hjem. Jeg kan næsten ikke faa i mit hovede, at $I$ nu ogsaa er bleven revet fra hinanden, og hvor maa det dog. være trist for ham at gaa der og 
drive tiden hen til ingen nytte; bare han dog ikke bliver syg. - Jeg kan nu ikke forstaa, at du er bleven indkaldt, og spørgsmaalet kredser stadig i mine tanker. Hvis det havde været almindeligt, at mænd $\mathbf{i}$ din alder havde faaet indkaldelsesordre, ja, saa havde det været kedeligt, men saa havde sagen været $\mathbf{i}$ sin orden. Det er imidlertid ikke vanskeligt at gennemskue, at din indkaldelse mere er møntet paa at gøre dig fortræd end gavne fædrelandet. Det er haardt, men du ved ikke, hvor jeg alligevel er glad for min gamle far. Ogsaa du er en af dem, der ikke svigter sin overbevisning for at høste personlig fordel. Det er saamænd let at gøre fortræd, naar man selv sidder paa det torre. Jeg er dog bange for, at disse herrer engang vælter med kareten. I dag kan man høre, at de igen er igang ved Verdun. Vi er dog altfor langt borte til, at det ogsaa skulde indvirke paa vor afdeling. Vi bor $10 \mathrm{~m}$ under jorden, saa det kommer sig ikke saa nøje her, om de sætter nogle svære brokker ovenpaa. - Blot du dog var bleven fri for dette, saa synes jeg endida, det kunde gaa an, men det hører vel op engang, og kan du huske, hvad der saa skulde staa i haven? (Tilf.: Sidste gang, han var hjemme, havde vi aftalt med hinanden, hvor flagstangen skulde staa.)

- Den 20. Oktober om aftenen begyndte de onde dage for os - kompagniføreren holdt en lille opmuntringstale til os, men det var ligesom han ikke selv troede paa sine ord, og vi ved jo ogsaa nok, hvad der vanker i Flandern. Hvad jeg oplevede i august i fjor var kun legeværk mod dette her. Vi er fire mand om at dele lejligheden, som vel maaler halvanden kvadratmeter og er en halv $m$ høj. Som fugleunger i en rede varmer vi hinanden, men det volder vanskelig- 
hed at finde en stilling, man kan taale at ligge i. Der er spændt et teltplan over os, for at flyverne ikke skal se os. De sidste dages regn har skabt et forfærdeligt ælte, og granathullerne er fyldte med vand. Granaterne opfanges af den bløde jord, og de synker bort uden at krepere. Det ryster under os, og vi oversprøjtes af snavs, men ellers sker der intet. Den første nat forløber roligt, men nu er de vist ved at staa op derovre. "Ratsch", og saa igen "ratsch". Jord og snavs slaar ned paa teltdugen, og en granatstump slaar igennem og bliver liggende paa min sidemands kappe. Den er helt varm. At man da ogsaa skal ligge her, blot for at lade sig mase. De enkelte eksplosioner kan vanskeligt skelnes fra hinanden, og jorden næsten gynger under os. Flyverne bliver mere og mere nærgaaende, og ilden holder sig med betænkelig ihærdighed paa kompagniets opholdssted. Et par haandgranater, som ligger ovenfor vor hule, gaar med i løbet. Det, er lange timer, som sikkert har kostet blod i kompagniet. Jeg trækker teltet tilside i nabohullet. Som om de sov, ligger Meyer og hans kammerat ved siden af hinanden. De har faaet en hurtig død: et sprængstykke har knust hjerneskallen paa dem begge. Da ilden hen ad eftermiddagen stilnede af, og jeg kryber ud for at orientere mig en kende, finder jeg nogle ukendelige menneskelegemer. Døden har høstet rigeligt, og kompagniet er svundet stærkt ind. - Henad morgenstunden sætter beskydningen ind igen, men varer dog kun en times tid. Den trækker længere til højre og stiger med en voldsom kraft. En ordonnans alarmerer os til at være parate. Jeg stikker hovedet frem og opdager, at der er kommet liv i signalraketterne. Vort artilleri sætter ind med spærreild, saa maa der være et an- 
greb i vente. Man anser det altid for en lettelse, naar man ved, hvad der foregaar, men her ved man intet. Opholdet her bliver utaaleligt. Min sidemand er bleven syg, og uden at kunne røre sig, kaster han op. Jeg springer ud og lægger mig ved randen af et vandfyldt granathul. De faa spring har ligesom gjort underværker i de stive lemmer. Da jeg rakker efter min spade for at skabe et bedre liggested, opdager jeg, at min venstre haand bloder: en granatsplint har revet en flænge i huden. Efter selv at have lagt en forbinding om saaret, springer jeg efter min bøsse og anden udrustning, raaber til de andre, at jeg er saaret og tænker kun paa at komme ud af clette helvede. Nogle faa hundrede meter borte ligger en forbindingsstation i en overjordisk rementdækning, og her tager læegen imod mig. De to derpaa folgende dage var jeg næsten ulle af stand til at foretage mig noget, kunde hverken sove eller være vaagen. Med stort besvær fik jeg mine sager gjort istand. Min bøsse var helt ubrugelig. Jeg havde ikke været $i$ stand til at afgive et eneste skud med len, dersom det. havde været nødvendigt. Mange andre har haft det paa samme maade. Som et værgeløst maal for fjenden ligger man derude. Tre dage senere kom kompagniet ud af stillingen; det var nu kun en lille flok, og mange kræfter havde de ikke. To dage senere blev vi atter alarmeret, rykkede i reserve, ventede en dag paa at komme tilbage igen, men om aftenen gik det ud i forreste linje for at afløse. Kort før vort bestemmelsessted opdagede englænderne os, og vi havde besvær med at naa vort maal, da der stadig blev skudt paa os med maskingeværer. Det gav en del saarede, deriblandt begge mine sidemænd. Vi laa omtrent som første gang, men kun $40 \mathrm{~m}$ fra mod- 
standeren, og saa havde jeg faaet den utaknemlige opgave at holde forbindelsen vedlige med nabokompagniet, som laa i en afstand af 200 meter. Der kunde modstanderen altsaa roligt spadsere igennem, men saa slemt blev det nu ikke.

- Efter to dages rejse er jeg nu atter kommet til Lecluse. Nogen fornøjelse er det ikke at foretage udflugter i denne tid. Turen gik over Lassigny, Le Cateau, Valenciennes og Douai, og da jeg kom hertil, fik jeg at vide, at jeg igen skulde tilbage til kompagniet, og at jeg for en halv snes dage siden er bleven forfremmet til underofficer, eller som vi kalder det i soldatersproget: har faaet kartoffelskrælling om kraven. Kompagniet kom i aften ud af stillingen, saa vi faar nok ro nu en uges tid. Stillingen er ikke rolig, og man kunde jo nok se, hvor kompagniet kom fra. Englænderne skyder meget med gas, tildels med 99 pCt. fosgen, saa den mindste indaanding medfører døden. Gassen er dog synlig, og har man faaet gasmasken paa i rette tid, er der ingen fare. Der fortælles, at de ogsaa har forsøgt med en anden ligesaa giftig gasart, som baade er lugtfri og ikke kan ses. I Flandern blev der ogsaa skudt med gas, men den foraarsagede kun hoste eller i værste tilfælde opkastning. Hele den gashistorie er ikke saa farlig, naar der vaages omhyggeligt og passes paa. Til andre tider er der ogsaa gjort forsøg paa at skyde med blind gas, hvilket vil sige, at der blev skudt med en ganske uskyldig gasart, og følgen var, at gasmaskerne kom frem og gjorde forsvaret vanskeligere. Modstanderen benyttede sig af denne list og angreb selv uden maske. Det skal være lykkedes godt første gang, ikke her, men en saadan spøg kan ikke saa godt gentages. 
"Vestfronten" er vort nyeste udtryk for at gaa i stilling, vort maal var denne gang landsbyen Fontaine sur Croiseller, lige tilvenstre for den by, hvor vi var sidst. Oppakningen, som mandskabet havde med, var saa stor, at vi brugte fem timer til de $8 \mathrm{ki}$ lometer. Noget, som egentlig ikke skulde ske ved fronten, var dette, at gruppen, vi skulde afløse, var forsvunden, før vi kom, og alt laa hulter til bulter. Med korte mellemrum slaar maskingeværernes projektiler baade fra højre og venstre, saa jeg tvinges til at lægge mig paa maven. Vi ligger temmelig langt fra modstanderen, men ellers - i forhold til siderne - noget fremskudt. Henad morgenstunden brølede vagten "angreb« ned i dækningerne. En saadan besked virker elektriserende, og $i$ et ojeblik havde vi indtaget vore stillinger, hvor vi blev rigelig betænkt med artilleriild, og infanterikuglerne hvislede om orerne. Signalkuglerne forlangte spærreild. Vor feltvagt var endnu i god behold, og jeg kunde heller ikke se nogen englænder nærme sig den. Det viste sig senere, at der slet ikke havde været tale om noget angreb, derimod havde en patrulje fra vor stormtrop forsøgt at nærme sig den engelske linje og haft held til at faa fat i en lyttepost. Englænderne, som maaske tænkte paa et større overfald, forlangte spærreild ved udskydning af farvede lyskugler. Farven skiftes derovre ligeom hos os; og nu gik det hverken værre eller bedre, end at farven den dag var den samme, og en maaske altfor ivrig signalpost paa vor side troede, at det gjaldt ham, og han sendte derfor englændernes signal videre til artilleriet. Følgen blev, at patruljen maatte give slip paa sit bytte, da den kom til at ligge $i$ heftig artilleriild fra begge sider, og vi andre blev narrede til at tro, at englænderne vilde hente os. 
Da vi senere begyndte at rydde op i dækningen, som en gang var bleven sprængt og senere tilkastet med gammelt skrammel stak pludselig en soldats støvler frem. Hvem var det, og hvorlænge havde han ligget der, eller var der maaske flere. Dakningen var nu ubrugelig for os, og det var ikke vor opgave at anstille nærmere undersøgelse angaaende liget. Der blev atter kastet jord paa, og saa ligger nu den ulykkelige i sin "heltegrav", medens der i et hjem forgæves ventes efter efterretning. Paa lignende maade gaar det med saa mange, der er meldt savnet. Det strider haardt mod ens følelser at se et lig saadan kastet hen som et ubrugeligt redskab. Maaske gaar det ogaa eder som os herude, at man bliver saa sløvet over for den slags.

I gaar aftes vendte vi tilbage efter en meget haard kampuge, jeg er som sadvanlig sluppen godt fra det, men mine to nordslesvigske kammerater er begge bleven saarede, Madsen fra Adsbøl endda temmelig haardt. Jeg fandt ham, og vi ligger nu nede $\mathbf{i}$ den gamle stilling. Vi skulde have boet i en forladt engelsk barak, men det vilde englænderne ikke have. Vi har nu lavet os nogle huller i vejgrøften og maa ligge og se paa, hvorledes de dejlige barakker skydes i klump. Her er imidlertid heller ikke megen sikkerhed, og naar det forst er bleven mørkt, skal vi have bygget os en rede et andet sted. Det hedder sig, at vi ikke gaar videre, og der ventes nu med spænding paa, hvor langt de kommer andre steder.

- Den 5. april 1918: Kære forældre, jeg blev saaret den 2. ds. Det værste er allerede overstaaet, men foreløbig maa jeg have ro. For mit vedkommende er krigen nok overstaaet.

Den 10. April: Den bedste tid er altid for mig, 
naar formiddagens forbinding er overstaaet. Det er ikke altid nogen let overgang, men smerterne formindsker sig, og jeg kan mærke, at det gaar langsomt fremad. Venstre ben er bleven gennemslaaet under knæet af en større granatsplint. Højre ben har faaet et kodsaar under knaet, ogsaa af en granatstump. En tredie har revet sædet stærkt op, og dette volder mig flest bryderier. Venstre haand har faaet tre, højre haand et saar, men de er dog temmelig ubetydelige $\mathrm{i}$ forhold til de andre, og de generer mig heller ikke videre. Naar jeg ogsaa har faaet en mængde saar, maa jeg dog vare glacl, at det altsammen kan heles igen. Jeg maa mindst holle sengen i nogle maaneder, og megen gavn faar jeg nok ikke af venstre ben $i$ dette aar, men saalange krigen varer, kan det jo vare ligemeget, hvor man uriver tiden hen. Jeg tænker dog ikke, opholdet skal vare ret læange her, saa gaar det med lasarettog i retuing imod Tyskland. Jeg tror, jeg kan komme i narheden af hjemmet.

Den 12. april: Solen skinner, og fuglene synger udenfor. Det er saa fint vejr, og jeg ligger her og kan ikke rore mig. Kunde man blot faa lov til at vare cierhjemme. Her faar man forst at vide, hvilken lykke det er at kunne spasere paa sine egne ben i guis frie natur. I gaar fik jeg en stump ben fjernet i let dybe saar paa venstre ben. Stumpen er ca. 1 ' 'm tyk og 2-3 cm lang - jeg har gemt den, og nu har jeg faaet et gummiror i saaret.

I kan ellers tro, vi satte ojnene paa stilke, la vi først var komme ind i de engelske linjer og tik at se, hvad de havde at leve af. Der var overfyldt med de fineste delikatesser, ingen "er'satz«. Deres telthug var endnu det rene gumni, deres dækkener vævede af 
Let rene uld. Jeg havde faaet samlet mig en del gode smaating, men hvad jeg ellers havde med, gik tabt, da jeg blev saaret. Kun det, jeg havde i lommerne, har jeg beholdt. Seks blev dræbt og syv saaret af den granat, som ramte mig. Jeg havde faaet nyt tøj; det maatte skæres af mig altsammen. Granaterne slog ned i nærheden, saa I-kan forstaa, at tankerne drejede sig ikke om andet end at komme bort. Derfor gik næsten alt tabt for mig. - Jeg har jo fortalt eder, l.vilke saar jeg har faaet, saa det er vel ikke nødvendigt, at jeg beder lægen om at skrive dem op igen. I kan vere ganske rolige, der er ikke flere, og det er ikke mere farligt, end jeg allerede har fortalt. Nogen livsfare er der ikke. Lægen og liegepersonalet her har hienderne fulde, og de, der kommer herind, er haarlt saarede. Mange dør straks, naar de kommer. For dem, der har været her i flere dage, synes faren overstaaet.

Den 27. April: Erede Hr. Dau. De har sikkert allerede faaet at vide, at deres son, underofficer Thorvald Dau, for nogen tid siden blev indlagt her som haardt saaret. Som landsmand har jeg ofte spurgt ham, om han skrer hjem, og han har altid hævdet, at han regelnæssigt holdt sine nærmeste underrettet. Om han stadlig kan gøre det, ved jeg ikke, da han er saa haardt medtaget af sine saar, at materieudsondringen for hver dag der gaar, forringer hans tilstand. Desuden er der kommet en halsbetændelse til, saa han kun med besvær kan overtales til at tage noget til sig, og hans appetit har i forvejen været meget daarlig. Hvis han ikke kommer sig lidt $i$ de narmeste dage, mener stabslægen ikke at kunne give meget haab $\mathrm{cm}$ en bedring. Han har ikke mange smerter, $i$ hvert fald lader han sig ikke mærke med dem, og 
han bærer sit kors med stor taalmodighed. Saasnart der indtræder en forandring, skal jeg nok underrette dem. J. J. -

Thorvald Dau døde paa lasarettet, og det haab, han stadig lader skinne igennem $i$ sine sidste breve, at han skulde komme til sin hjemegn for at gaa en bedring og en god fred i møde, blev ikke opfyldt. Han sidste hvilested fandt han dog i vennejord i Braisne. 